\title{
Sérnám í forgrunni
}

Læknanám á Íslandi á sér langa sögu og hefur að minnsta kosti síðustu 50 árin pótt gott. Framhaldsnám hefur hins vegar lengst af verið takmarkað og óskipulagt. Læknar fóru pví oftast fljótlega úr landi eftir kandídatsárið til að læra pá sérgrein sem peir völdu. Fyrir vikið misstu heilbrigðisstofnanir landsins af mikilvægum starfskrafti par til fullmenntaðir sérfræðilæknar komu til baka, ef pað gerðist. Sérnámsárin, pegar atorka og vinnugleði eru í hámarki, féllu erlendum námsstofnunum í skaut. Rannsóknanám í Háskóla Íslands var líka óvanalegt fram undir síðustu aldamót. Peir sem öfluðu sér æðri háskólagráðu gerðu pað á erlendri grund að mestu leyti. Nefndir voru stofnaðar til að reyna að efla sérnám hér á landi og skýrslur voru gerðar. Málefninu pokaði löturhægt áfram. Ófullkomin lög og gamaldags reglugerð um sérnám lækna, ásamt pví viðhorfi að innlendar stofnanir skorti burði til að bjóða sérnám og að enginn væri maður með mönnum nema hún eða hann hefði eytt árum erlendis, unnu gegn pví að sérnámi væri komið á fót.

Síðastliðinn aldarfjórðung hafa loks orðið umbætur. Heimilislæknar voru í forystu og settu upp fullt sérnám með marklýsingu og gæðakröfum. Eftir setningu nýrrar reglugerðar um starfs- og sérnám lækna vorið 2015 hefur orðið veruleg breyting. Flestar, en pó ekki allar, megin sérgreinar læknisfræðinnar bjóða nú sérnám. Í premur er boðið fullt nám, aðrar eru með upphafsnám í 2-3 ár. Lágmarkstími sérfræðináms er 5 ár í samræmi við evrópskar reglur. Eins og lýst er í grein Tómasar Pórs Ágústssonar í pessu blaði hafði nýja reglugerðin nr. 467/2015 mun fastari ákvæði en áður um að starfsnám (nýtt nafn á „kandídatsári“) og sérnám gæti aðeins farið fram í fastákveðnu skipulagi, par sem nákvæm marklýsing um framvindu námsins er notuð og stöðugt námsmat fer fram. Námsstaði parf að viðurkenna með formlegum hætti.

Til að annast eftirlit með pessu var sett á fót svokölluð mats- og hæfisnefnd sem parf að viðurkenna marklýsingar og námsstaði. Formlega viðurkenningu má líta á sem ákveðinn gæðastaðal fyrir námsstaðinn. Til pessa hefur nám í heimilislækningum, geðlækningum, barna- og unglingageðlækningum, bæklunarlækningum, lyflækningum, meinafræði og réttarmeinafræði verið viðurkennt og skammt er í að við pað bætist barnalækningar, bráðalækningar, fæðinga- og kvensjúkdómalækningar, sampætt kjarnanám í bráđalækningum („,bráðakjarnaleiðin“), skurðlækningar, svæfinga- og gjörgæslulækningar og viðbótarnám í öldrunarlækningum. Pá er í nokkrum öðrum sérgreinum verið að skoða upphafsnám eða svokallað viðbótarnám ofan á annað sérnám, en undirsérgreinanám er ekki tímabært enn sem komið er. Allt parf petta að standast gæðakröfur sem eru sambærilegar við pað sem gerist í nágrannlöndum austan og vestan hafs. Samvinna er um petta milli Landspítalans, heilsugæslunnar og Sjúkrahússins á Akureyri. Sérnámsstöður lækna á nú ekki að auglýsa nema pær hafi hlotið viðurkenningu mats- og hæfisnefndar. Nefndin parf líka að viðhafa eftirlit með pví að námsstaðlar drabbist ekki niður. Nokkrar mikilvægar sérgreinar vantar pó enn til að framboð sérgreinanáms taki til flestra megin sérgreina, pað er að segja um ríflega priðjungs peirra sérgreina sem Evrópusamtök sérfræðilækna hafa viðurkennt.

Ávinningur sérnáms á Íslandi, að hluta eða öllu leyti, er augljós. Gæðaaukning verður í heilsugæslu og spítalastarfi, sérlega góður starfskraftur á lægri launum en sérfræðilæknar bætist við og hættan á að missa lækna til frambúðar úr landi minnkar. Fjárfestingin úr háskólanáminu skilar sér betur. Að íslenskum sið gera stjórnvöld samt ekki ráð fyrir kostnaði af sinni hálfu og velta pví yfir á heilbrigðisstofnanirnar. Utanumhald og eftirlit parf, bæði kennslustjóra og aðstoðarfólk peirra og mats- og hæfisnefndarstörfin eru umfangsmikil og munu vaxa. Að ætlast til pess að til langframa verði petta tekið af núverandi fjárveitingum stofnana er ekki rétt. Hófleg fjárveiting mun skila sér til baka. Um leið parf að skipuleggja tengsl við akademískt nám á meistara- og doktorsstigi fyrir unga sérnámslækna.

Darf sérnám á Íslandi? Má ekki bara hafa petta eins og pað var? Svarið er að breyttar aðstæður heima og erlendis kalla á að tíminn sem unglæknar eyða á Íslandi eftir kandídatsár verði lengdur og nýttur sem best. Námstími hér parf líka að vera viðurkenndur pegar komið er til útlanda. Til pess parf samninga við stofnanir og heilbrigðisyfirvöld í helstu námslöndum íslenskra unglækna. Önnur lönd krefjast pess að nám hafi marklýsingu og að opinbert sampykktar- og eftirlitskerfi sé til staðar. Margir ungir læknar vilja forðast eða stytta dvöl á erlendri grund. Mönnun heilbrigðisstofnana með millistigslæknum í stöðluðu og góðu sérnámi eykur gæði heilbrigðispjónustunnar.

Nú verður ekki aftur snúið. Sérnám er komið til að vera á Íslandi, sem betur fer.

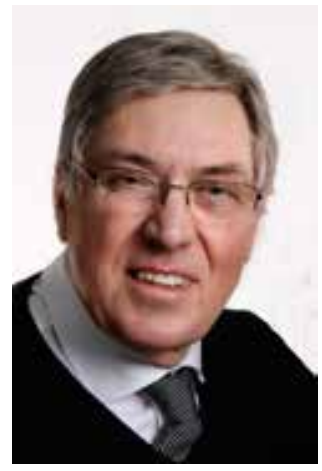

\section{Reynir Tómas}

\section{Geirsson}

fyrrv. prófessor og forstöðulæknir, formaður mats- og hæfisnefndar skv. reglugerð nr. 467/2015

reynirg@landspitali.is

\section{Specialist education at the fore}

Reynir Tómas Geirsson, MD, $\mathrm{PhD}$, FRCOG, emeritus professor of obstetrics and gynecology, chairman of the Evaluation and Accreditation Committee for specialist education, Landspitali University Hospital, Reykjavik.

doi.org/10.17992/lbl.2018.10.199 